\title{
Determining The Impact Of Capitalising Long-Term Operating Leases On The Financial Ratios Of The Top 40 JSE-Listed Companies
}

Rikus R de Villiers, KPMG, South Africa

Dr Sanlie L Middelberg, North-West University, South Africa

\begin{abstract}
Operating leases form a great part of companies' financing structures in today's economic environment. Some accounting standard-setters and other users of financial statements are of the opinion that the current standard on accounting for operating leases, IAS 17, does not provide sufficient guidelines on the disclosure of a company's leasing activities. The current accounting standard on leases provides companies with the opportunity to classify lease contracts into different classes which leads to off-balance-sheet financing. This problem is currently being addressed by the IASB as they are in the process of developing an improved standard on leases.
\end{abstract}

The main focus of this paper is to determine the impact of the improved accounting standard on the financial statements and the resulting financial ratios of the JSE Top 40 companies when operating leases are accounted for as on-balance-sheet debt. The differences between the current IAS 17 and the Exposure draft (ED/2010/9) are identified and the comparison indicates significant differences between these two approaches on accounting for operating lease activities.

The focus of the IASB in developing this exposure draft was to provide the users of financial statements with a universal picture of the leasing activities that the company is engaged in. The findings include that this objective is achieved as users are not left uninformed about any of the financing activities that stakeholders are exposed to if indeed a company is engaged in operating lease activities. The study also revealed that the capitalising of long-term operating leases will have a significant effect on the key financial ratios that stakeholders use to interpret a company's financial performance.

Keywords: Capitalising; Financial Ratios; Finance Lease; Long-Term Operating Leases; Off-Balance-Sheet Financing; JSE Top 40

\section{INTRODUCTION}

\section{Background}

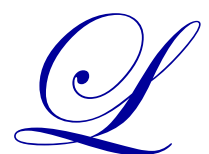

easing is an important source of financing assets in the South African economic environment. A lease can be defined as an agreement whereby the lessor has conveyed the right to use an asset for a period of time for a series of payments by the lessee (IASB, 2009a:1200). It is therefore important that the accounting treatment of leases is in such a way that the users of the financial statements cannot only interpret the information, but also obtain a universal picture of the leasing activities of the company.

Two of the major global standard-setters are the International Accounting Standards Board (IASB) and the Financial Accounting Standards Board (FASB). The accounting standard dealing with lease accounting is the 
International Accounting Standard (IAS) 17, while its United States (US) counterpart is General Accepted Accounting Practice (GAAP) Codification No. 840 (IASB, 2009a:1201; US GAAP, 2011). Currently, both the International Financial Reporting Standard (IFRS) in IAS 17 and US GAAP classify leases into two classes: 1) operating and 2) financial leases (Bryan, Lilien \& Martin, 2010:36). According to the latest edition of IAS 17, an operating lease is one that is not classified as a finance lease and a finance lease is one where substantially the rewards and risks incidental to ownership of the asset are transferred from the lessor to the lessee (IASB, 2009a:1201).

Standard-setters, such as the IASB, are of the opinion that the current accounting standard on leases does not provide clear enough guidelines on the disclosure of assets and liabilities that arise from leasing contracts. Furthermore, the notes to the financial statements do not contain enough information for the users of the financial statements to adjust the figures so they can get a better understanding of the company's leasing activities (Grossman \& Grossman, 2010:6). The fact that leases can be classified into operating leases rather than finance leases holds a great advantage because it creates opportunities for companies to have off-balance-sheet financing. Therefore, companies avoid on-balance-sheet debt (Fulbier, Silva \& Pferdehirt, 2008:123).

In 1996, a special report was put forward by the IASB and the FASB - named G4 + 1 - which suggested a new approach to the accounting treatment of leases; namely, that all leases with a term of more than one year should be capitalised. This report has developed into a project with the objective of developing a new standard for lease accounting, ensuring that the liabilities and assets that arise from lease contracts are included in the reported figures and are not just disclosed in the notes to the financial statements. The effect of this approach is that all leases would be accounted for as finance leases and therefore no off-balance-sheet financing in connection with lease contracts would appear in the financial statements (Fulbier et al., 2008:122-123).

\section{Motivation Of The Study}

The proposed capitalisation of all operating leases would have an effect on both the total and current liabilities of companies that are currently reporting operating leases in the disclosure of their financial statements (Grossman \& Grossman, 2010:6). This makes a study of this nature relevant in the business world of today. The effect of the proposed change of IAS 17 on financial ratios of companies engaging in leasing activities has to be investigated as this may affect the financial statements of companies significantly more than was originally anticipated.

The users of financial statements - also referred to as the stakeholders - primarily include investors, employees, lenders, suppliers, customers, governments, and the general public (IASB, 2009b:19). Users of the financial statements consider the effect of operating leases in their interpretation of the financial statements because of the impact it has on the financial risk the users are exposed to due to the lease contracts that must be completed (Beattie, 2000:1186; Imhoff, Lipe \& Wright, 1993:342; Ely, 1995:397). Therefore, when these users analyse financial statements by calculating financial ratios, the impact of operating leases is considered.

The effect of different accounting treatments for leases and financing has an impact on the decisions lenders make and the credit evaluations performed by them. It was found that lenders' decisions are affected by the actual level of leverage; i.e., debt to equity, and not by the way that companies account for leases in their financial statements (Wilkins \& Zimmer, 1983a:751; Wilkins \& Zimmer, 1983b:65). The remainder of this paper is set out as follows: Firstly, the problem statement and research objective will be formulated, followed by the research design. The research findings will be discussed and the paper will conclude with conclusions and recommendations, areas for further research, and research limitations.

\section{PROBLEM STATEMENT AND RESEARCH OBJECTIVE}

Companies prefer lease contracts to be classified as operating leases rather than those of finance. The question that arises is "What impact does the capitalisation of long-term operating leases have on the financial ratios used by users in their interpretation of the financial statements and, more directly, the stakeholders of JSE-listed companies?" Therefore, the primary question that needs to be answered is: 
- What effect does the capitalisation of long-term operating leases have on the key financial ratios that stakeholders use to interpret a company's financial performance?

In order to address this research problem, the main objective of this study was to determine the significance of the effect that capitalising long-term operating leases will have on the financial ratios of JSE-listed companies in South Africa.

\section{RESEARCH DESIGN}

To achieve the above objectives, a thorough literature review with an empirical study was conducted.

\section{Literature Review}

\section{Review Of Research Conducted}

Research conducted in both the United States and Canada (Durocher, 2008:230) has shown that since accounting standards on the capitalisation of leases had been introduced to the accounting world, the management of companies has constructed their lease contracts in such a way that they have much less finance leases in comparison to operating leases, hence avoiding the capitalisation of the lease liability. The main reason for doing this is to avoid the consequential debt that is shown in the Statement of Financial Position and the negative effect it may have on incentives for managers. Evidence collected more recently shows that managers will still enter into contracts with shorter lease periods to avoid the capitalisation of the lease (Beattie, Goodacre \& Thomson, 2006:79).

\section{Accounting For Leases - Classification Between Finance And Operating Leases As Per The Current IAS On Leases}

According to the current standard on lease accounting - IAS 17 - a lease agreement can be classified into one of two classes. The first is an operating lease, where the asset in substance belongs to the lessor and the lessee enjoys the use thereof without substantially obtaining the risks and rewards incidental to ownership. Lease agreements can be structured as such that the lessee, in essence, does not really lease the asset but instead, the lessor transfers the risks and rewards incidental to the ownership of the asset to the lessee, whereby classifying it as a finance lease (IASB, 2009a:1203). To classify a lease agreement into a finance lease or operating lease depends on the substance of the transaction rather than the legal form of the lease contract (IASB, 2009a:1204). IAS 17 identifies eight examples of situations where a lease is classified as a finance lease. These are also used as criteria to determine whether a lease agreement constitutes a finance or an operating lease. If one of the criteria applies, it is regarded that the risks and awards are substantially transferred and the lease is therefore classified as a finance lease (IASB, 2009a:1204). If the agreement does not meet any of the criteria, the lease agreement is classified as an operating lease. The accounting treatment of both financial and operating lease contracts differs for lessees and lessors. In this study, only the accounting treatment from the perspective of the lessee was considered. In order to determine the effect that the proposed changes of the accounting standard will have on financial ratios, the line items in the financial statements affected by the requirements of the current accounting standard are summarised in Table 1.

Table 1: Summary Of The Line Items Affected By The Current Accounting Standard On Leases

\begin{tabular}{|c|c|}
\hline \multicolumn{2}{|c|}{ LESSEE ACCOUNTING } \\
\hline FINANCE LEASES & OPERATING LEASES \\
\hline Statement of Profit \& Loss and other Comprehensive Income & $\underline{\text { Statement of Profit \& Loss and other Comprehensive Income }}$ \\
\hline$\overline{\text { Finance charges }}$ & $\overline{\text { Rent expense }}$ \\
\hline Depreciation & Current taxation \\
\hline Current taxation & \\
\hline Statement of Financial Position & Statement of Financial Position \\
\hline Finance lease asset & Asset or liability, only as a result of lease smoothing, i.e. \\
\hline Finance lease liability & (prepayment or accrual) \\
\hline Accumulated depreciation & \\
\hline Deferred tax & Deferred tax \\
\hline
\end{tabular}




\section{New Proposed Accounting Treatment On Leases}

A new accounting standard was developed to overcome the shortcomings of the current IAS 17. The new proposed accounting standard will ensure that the full effect of the leasing activities of a company is reflected in the financial statements of the parties entering into the lease agreement. The aim is also to represent true information regarding the timing, amounts and uncertainty of the cash flows that arise from leasing activities (IASB, 2010:5)

Table 2 presents the key line items in the financial statements that will be affected by the proposed change in lease accounting. These are from the perspective of the lessee and were identified based on the requirements set out in the exposure draft (ED/2010/9) (considering that impairment is recognised according to IAS 36 or revaluations performed according to IAS 16).

Table 2: Key Line Items Affected By The Proposed Change Of IAS 17 LESSEE ACCOUNTING

Statement of Profit \& Loss and other Comprehensive

Income

Finance charges

Amortisation

Current taxation

\section{Statement of Financial Position}

Right-of-use asset

Liability to make lease payments

Accumulated amortisation

Deferred taxation

After an in-depth comparison between the current IAS 17 on accounting for leases and the exposure draft (ED/2010/9), the differences and similarities are summarised in Table 3 according to initial recognition, initial measurement and subsequent measurement.

Table 3: Main Differences Between The Current IAS 17

And The Proposed Accounting Standard On Accounting For Leases From The Perspective Of The Lessee

\begin{tabular}{|c|c|}
\hline CURRENT IAS 17 & PROPOSED IAS 17 \\
\hline \multicolumn{2}{|l|}{ Initial Recognition } \\
\hline $\begin{array}{l}\text { At commencement of the lease term, lessees distinguish } \\
\text { between operating leases and finance leases. }\end{array}$ & $\begin{array}{l}\text { No distinction is made between operating and finance leases. } \\
\text { All lease contracts are recognised as finance leases. }\end{array}$ \\
\hline $\begin{array}{l}\text { Initially, a finance lease asset is recognised with a } \\
\text { corresponding finance lease liability. }\end{array}$ & $\begin{array}{l}\text { Initially, a right-of-use asset is recognised with a } \\
\text { corresponding liability to make lease payments. }\end{array}$ \\
\hline \multicolumn{2}{|l|}{ Initial Measurement } \\
\hline $\begin{array}{l}\text { Finance leases are initially recognised at the lower of the fair } \\
\text { value of the asset and the present value of the minimum } \\
\text { lease payments. }\end{array}$ & $\begin{array}{l}\text { Leases are recognised at the present value of the lease } \\
\text { payments. }\end{array}$ \\
\hline $\begin{array}{l}\text { The rate implicit to the lease is used to determine the present } \\
\text { value of the minimum lease payments. }\end{array}$ & $\begin{array}{l}\text { The lessee's incremental borrowing rate is used to determine } \\
\text { the present value of the lease payments. }\end{array}$ \\
\hline $\begin{array}{l}\text { The lease term is the non-cancellable term as specified in the } \\
\text { lease contract. }\end{array}$ & $\begin{array}{l}\text { The lease term is the longest term, more likely than not, that } \\
\text { the lessee is going to lease the asset. }\end{array}$ \\
\hline \multicolumn{2}{|l|}{ Subsequent Measurement } \\
\hline Finance Lease Liability & Liability To Make Lease Payments \\
\hline $\begin{array}{l}\text { Apportioning of lease payments into capital and interest } \\
\text { expenses. }\end{array}$ & $\begin{array}{l}\text { Apportioning of lease payments into capital and interest } \\
\text { expenses. }\end{array}$ \\
\hline Finance Lease Asset & Right-of-use Asset \\
\hline $\begin{array}{l}\text { Subsequently measured in accordance with IAS 16: Property, } \\
\text { plant and equipment. }\end{array}$ & $\begin{array}{l}\text { Subsequently measured in accordance with IAS 38: Intangible } \\
\text { assets. }\end{array}$ \\
\hline No revaluation of the asset per IAS 17 & $\begin{array}{l}\text { Revaluation may take place according to IAS 16: Property, } \\
\text { plant and equipment. }\end{array}$ \\
\hline No Impairment according to IAS 36: Impairment. & Testing For Impairment according to IAS 36: Impairment. \\
\hline
\end{tabular}

It should be noted that contingent rentals and leases shorter than one year were not included in this study. It is therefore clear that there are significant differences between these two approaches for the lessee on the treatment of operating leases from an accounting perspective. The effect of these differences on certain financial ratios will be illustrated later in the research study. The financial ratios considered to determine the effect of the proposed change in accounting for leases follow. 


\section{Financial Ratios}

Financial ratio analysis is used by the financial statement users to make certain assumptions about a company's performance and financial stability (Al-Ajmi, 2008:107; Etter, Lippincott \& Reck, 2006:146; Horrigon, 1965:558). Previously (see Table 3), the key line items in the financial statements that are affected by the proposed change of IAS 17 were identified. The aim was to link the line items in the financial statements affected by the proposed change of IAS 17 to the relevant financial ratios. The line items that are affected will have a direct impact on certain financial ratios, since these financial ratios are calculated using the line items that are affected. According to Fulbier et al. (2008:128), financial ratios can be divided into three broad categories that will provide a summary of the overall financial position of a company. These categories include 1) ratios that indicate the structural change within a company, 2) ratios that indicate the profitability of a company, and 3) ratios that have an impact on the valuation of companies from a market perspective. The proposed change in accounting for leases will have an effect on a number of figures in the financial statements, such as total debt, equity (through the changes in the amounts recognised in profit or loss and then accumulated in retained earnings) and return ratios (Correia, Flynn, Uliana \& Wormald, 2011:5-30). Table 4 indicates the financial ratios that were used in this study as they are affected by the proposed change in accounting for leases. The effect is not only limited to these ratios, but these are the ratios that will provide a clear indication of the effect the proposed change in accounting for leases will have.

Table 4: Financial Ratios That Indicate Structural Change In Financing Activities Of A Company

\begin{tabular}{|l|l|}
\hline \multicolumn{1}{|c|}{ RATIO } & CALCULATION FORMULA \\
\hline Financial Ratios That Indicate Structural Change \\
\hline Debt to equity & Total debt / Total equity \\
\hline Debt ratio & Total debt / Total assets \\
\hline Interest cover & Earnings before interest and taxation / Interest paid \\
\hline Financial Ratios That Indicate The Profitability Of A Company \\
\hline Net profit percentage & Net profit for the period / Revenue \\
\hline Return on equity & Net profit / Total equity \\
\hline Return on assets & Net profit / Total assets \\
\hline Financial Ratios Impacting Valuation Of Companies From A Market Perspective \\
\hline Earnings per share & (Net profit - Preference dividends) / Weighted number of ordinary shares \\
\hline Price-earnings ratio & Market price per share / Earnings per share \\
\hline
\end{tabular}

\section{Empirical Research}

In this study, a non-probability sampling technique, referred to as quota sampling, was used. The population was companies listed on the JSE. The sample selected from the population was the Top 40 JSE-listed companies based on their market capitalisation. The criterion used for the selection of the companies was the market capitalisation of the companies for 2010, as this was the most recent and applicable information. Each of these companies was analysed and only the companies that disclose operating lease agreements in their notes to the financial statements were included in the final sample.

A capitalisation model based on research performed by Fulbier et al. (2008:127) was used to estimate the remaining lease term and the lease payments remaining by applying this model to the disclosed operating lease information of the companies. This capitalisation model is discussed later. The second criterion that had to be met is that the model used in the study to determine the lease term should be applicable to the specific company. If this was not possible due to the reasons stated later, the company was excluded from the sample, even though it did disclose operating lease information. The reason for this was to ensure consistency in performing a comparison between the effect of the current - and proposed - accounting treatment for operating leases on financial ratios.

The initial sample size included 42 companies as provided by the JSE Ltd. to form part of the Top 40 . The reason why the initial sample includes 42 companies - and not the 40 as indicated earlier - is that some of the companies may have an equal market capitalisation and therefore are ranked evenly. Table 5 indicates the number of companies that did not meet the criteria as stated earlier, as well as the final sample size used in this study. 
Table 5: Final Sample

\begin{tabular}{|l|c|}
\hline & Number Of Companies \\
\hline Initial sample size & 42 \\
\hline No operating lease disclosure in the notes to the financial statements & -6 \\
\hline Model not able to be applied to companies & -7 \\
\hline Final sample size & $\mathbf{2 9}$ \\
\hline
\end{tabular}

The published financial statements of these companies represent the required data, thereby making use of quantitative methods of collecting data. The data published in the financial statements was analysed.

\section{Data Analysis}

An in-depth analysis of the disclosed operating lease agreements in the annual financial statements of the sampled companies was performed. The data analysis (without reversing the current operating lease expense as recognised in the financial statements) was performed in six steps in order to compare the effect of the proposed accounting standard on operating leases on financial ratios. These steps are indicated in Figure 1.

Figure 1: Steps In Analysing The Effect Of The Proposed Change In IAS 17

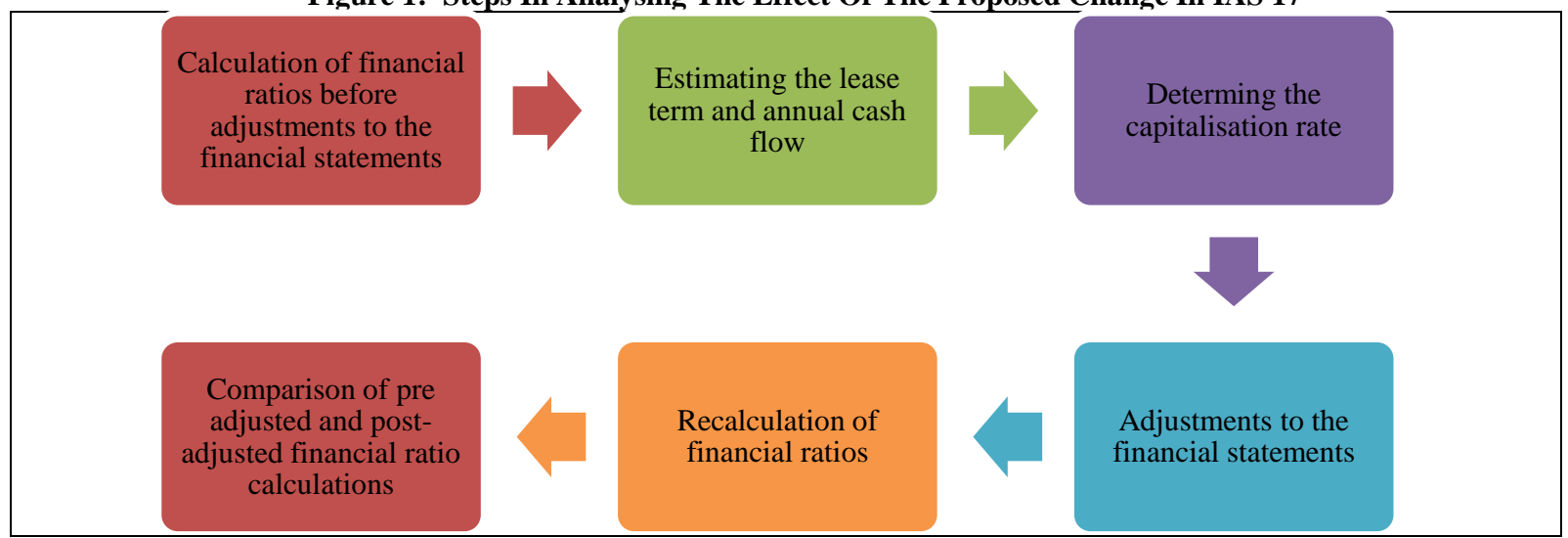

The disclosure of the resulting asset or liability that arises from the operating lease payment smoothing is not required by IFRS and therefore companies do not disclose this information; thus it was not possible to reverse the operating lease expense recognised in the reported financial statements. However, one company in the sample did disclose the resulting asset or liability due to payment smoothing voluntarily and, consequently, the effect of the reversal on the financial ratios and the capitalisation effect of future minimum lease payments were calculated. There was no significant difference noted as the effect on the financial ratios was smaller than $1 \%$. Each of the steps, as indicated in Figure 1, will now be discussed.

\section{Step 1: Calculation Of Financial Ratios Before Adjustments To The Financial Statements}

The relevant financial ratios were calculated for each of the sampled companies by using the data obtained from the published financial statements and the notes to these financial statements. These financial ratios were calculated before any adjustments were made to the financial statements as proposed by the new accounting standard on leases. The next step was to determine the remaining lease term and the annual cash flow.

Step 2: Estimating The Lease Term And Annual Cash flow

According to the current IAS 17 (IASB, 2009a:1213), companies must disclose the future minimum lease payments for the following year, the four years following this, and the period thereafter.

The proposed accounting treatment for operating lease agreements indicates that all operating lease agreements must be capitalised over the remaining lease term at the present value of the future minimum operating 
lease payments (MLP) (IASB, 2010:10). To apply this proposed principle, the remaining lease term and the operating lease payments for each year needed to be calculated. The disclosure requirements of IAS 17, as mentioned above, do not require the disclosure of individual lease agreements. Therefore, companies group the operating lease agreements together. It was not possible to isolate the annual payments as needed to determine the annual cash flows and to identify the estimated remaining term of the lease agreements.

Research conducted by Fulbier et al. (2008:127) assumed that the lease payments will decline at a constant rate over the remaining lease term of the agreements because as time passes, contracts come to an end. Therefore, Fulbier et al. (2008:127) created a capitalisation model (Figure 2) that uses a digression factor (dg) in order to segregate the annual payments out of the disclosed information in the notes to the published financial statements. In this study, the same model was applied to determine the operating lease expense or cash flow for the following year and years 2 to 5 .

Figure 2: Capitalisation Model

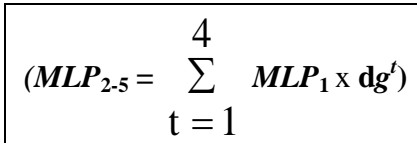

Source: Fulbier et al. (2008:127)

The digression factor (dg) and annual cash flows were obtained using Microsoft Excel to calculate both the digression factor and the cash flows as disclosed in the notes to the financial statements of the sampled companies. Each disclosure requirement was used as a variable in the capitalisation model in order to calculate the digression factor as seen in Table 6 .

Table 6: Relationship Between Disclosure Requirements And Variables Used In The Capitalisation Model

\begin{tabular}{|l|c|}
\hline DISCLOSURE REQUIREMENTS & VARIABLE \\
\hline Minimum rent payment due in the following year & $\boldsymbol{M L P}_{\mathbf{1}}$ \\
\hline Minimum rent payment due after the following year but not later than five years & $\mathbf{M L P}_{\mathbf{2 - 5}}$ \\
\hline Minimum rent payment due after five years & N/A \\
\hline
\end{tabular}

The capitalisation model referred to assumes that the minimum operating lease payments decline at a constant rate over time. The model uses a digression factor that is persistent over five periods, with $\boldsymbol{M L P} \boldsymbol{P}_{t+1}=$ $\boldsymbol{M L P}_{\mathrm{t}} \times \boldsymbol{d g}$. The known $\boldsymbol{M L} \boldsymbol{P}_{\mathbf{1}}$, as disclosed in the notes to the published financial statements, determines the unknown $\boldsymbol{M L P} \boldsymbol{P}_{2}, \boldsymbol{M L P} \boldsymbol{P}_{3}, \boldsymbol{M L P} \boldsymbol{P}_{4}$, and $\boldsymbol{M L P} \boldsymbol{P}_{5}$ that are grouped together in the disclosure requirements. The data-solver function of Microsoft Excel was used to determine the digression factor by ensuring that if the digression factor is

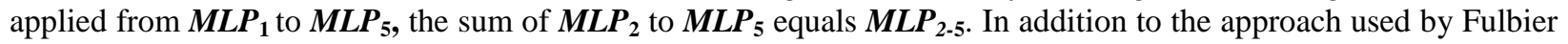
et al. (2008:127), the digression factor was used on the payments due after five years to estimate the cash flows, as well as the remaining lease term after year 5. The current year's payment was determined by taking $\boldsymbol{M L P}_{\mathbf{1}}$ and appreciating it by the digression factor. This study contributes this enhancement to the study performed by Fulbier $e t$ al. (2008). It is also the first study of this nature in South Africa.

\section{Step 3: Determining The Capitalisation Rate}

The third step in the six-step process, as indicated in Figure 1 and which analyses the effect of the proposed change of IAS 17, is to determine the capitalisation rate. The proposed IAS 17 prescribes that the future minimum operating lease payments should be capitalised at their present value at the commencement of the lease by using the incremental borrowing rate as the discount rate (IASB 2010:20). The incremental borrowing rate is the interest rate that the company would have to pay if indeed they were to borrow the money to buy the asset instead of leasing it (IASB, 2010:39-40). It is not possible to determine this rate for each of the sampled companies because it will differ from company to company based on factors such as 1) the creditworthiness of the company and 2) the credit risk the company poses to its financiers (Anon, 2009). To ensure consistency and because this rate is the one that most companies are subjected to, the current South African prime interest rate of $9 \%$ was used as the incremental borrowing rate (Anon, 2011). The rate will enable a comparison between the effect of capitalising operating lease agreements on financial ratios and the current accounting treatment. The repo rate was not used because only six 
companies in the sample will pay interest at the repo rate as only six financial institutions form part of the sample. The repo rate is the interest rate at which financial institutions borrow from the South African Reserve Bank (Mohr, 2011:177).

Steps 4 and 5: Adjustments To The Financial Statements And Recalculation Of Financial Ratios

The fourth and fifth steps in the six-step process are to make adjustments to the financial statements and then to recalculate the financial ratios. The financial ratios were recalculated using the adjusted balances of the reported financial statements to include the effect of the capitalisation of future minimum operating lease payments.

Step 6: Comparison Of Pre-Adjusted And Post-Adjusted Financial Ratio Calculations

The last step in the six-step process was the comparison of pre- and post-adjusted financial ratios as calculated. The findings of these calculations will now be discussed.

\section{RESEARCH FINDINGS}

The findings of this research study will be reported for each category of financial ratios as identified by Fulbier et al. (2008:128).

\section{Financial Ratios That Indicate Structural Change Within A Company}

The structural change within a company refers to the change between the financing structures of the company; i.e., whether the company is financed through debt or financed through equity, or a combination of both. The financial ratios that are affected by either equity or debt include the 1) debt ratio, 2) debt-to-equity ratio, and 3) interest cover. The capitalisation of operating leases will affect both the total assets and liabilities of a company because a right-of-use asset should be recognised together with a corresponding lease liability as per the proposed accounting treatment. Interest charged to the statement of Profit \& Loss and other Comprehensive income due to the effect of the subsequent measurement required by the proposed accounting standard will affect the interest cover of the company.

Graph 1 indicates the financial ratios before and after adjustment to the financial statements for the capitalisation of operating leases. The results for each of the above-mentioned financial ratios will now be discussed individually.

Graph 1: Financial Ratios Indicating Structural Change Before And After The Adjustments For Capitalisation Of Operating Leases

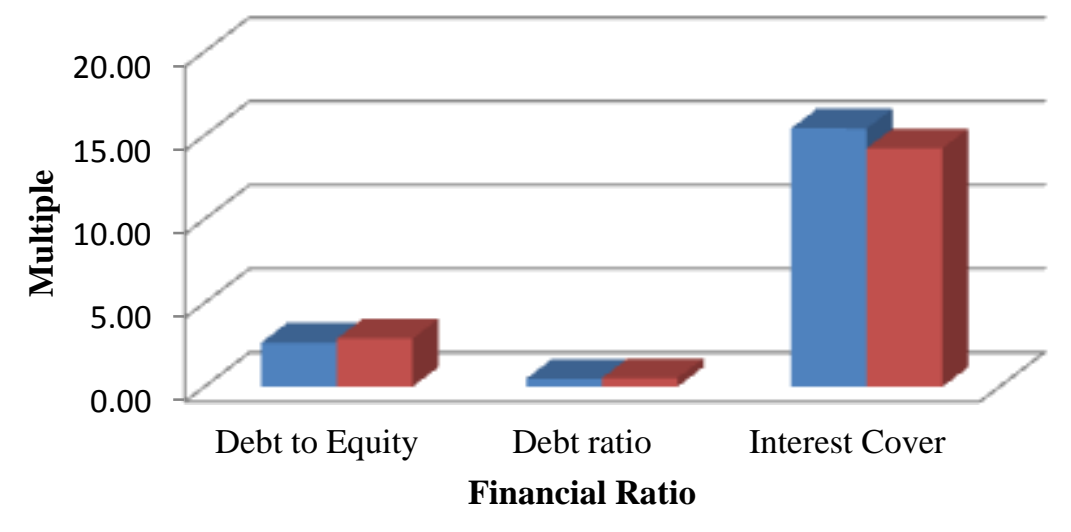

- Before Adjustments - After Adjustments 


\section{Debt-to-equity Ratio}

The debt-to-equity ratio indicates the level of financial risk that the company is exposed to (Correia et al., 2011:5-16; Nadarajah \& Kotz, 2007:995). In the total sample, the average debt-to-equity ratio of the Top 40, included in the final sample, equalled 2.63 before any adjustments were made to the financial statements to account for the proposed accounting treatment change of operating leases. After the adjustments to the financial statements, the debt-to-equity ratio increased to 2.87 . This results in a percentage change of $9 \%$. Therefore, if this proposed change is implemented, the company would seem more risky from a financial perspective which may cause investors to rethink their investment decision in the company as they would be exposed to higher financial risk.

\section{Debt Ratio}

Assets are usually funded by debt or equity (Lin, Liang \& Chen, 2011:15095; Koen \& Oberholzer, 1999:52). The debt ratio indicates the portion or percentage of the total assets that is funded through debt financing. The average debt ratio for the sampled companies, before any adjustments, accumulated to 48\%. After adjusting the financial statements, the average debt ratio increased to $52 \%$ for the entire sample, thereby resulting in an average increase of $8 \%$. This is a clear indication that operating leases are a form of off-balance-sheet financing, as referred to earlier (see Graph 2).

\section{Interest Cover}

The last selected ratio that indicates structural change within a company is the interest cover ratio which indicates a company's ability to pay its interest instalments on the date that it is due and the multiple by which a company's earnings may decrease before they would not be able to meet their interest obligation (Vigario, 2008:238; Nadarajah \& Kotz, 2007:995). The average interest cover for the entire sample equalled 15.42 which indicates that total earnings are 15.42 times higher than the current interest payments.

After adjusting the financial statements with the proposed changes, the interest cover decreased to an average of 14.24 due to the interest that is recognised in the statement of Profit \& Loss and other Comprehensive income, as suggested by the proposed new accounting standard on operating leases. The average change in the interest cover represents a decrease of $8 \%$ which supports the statement that the interest expense that is recognised will decrease the earnings of a company.

Graph 2: The Average Percentage Change For Financial Ratios That Indicate Structural Change

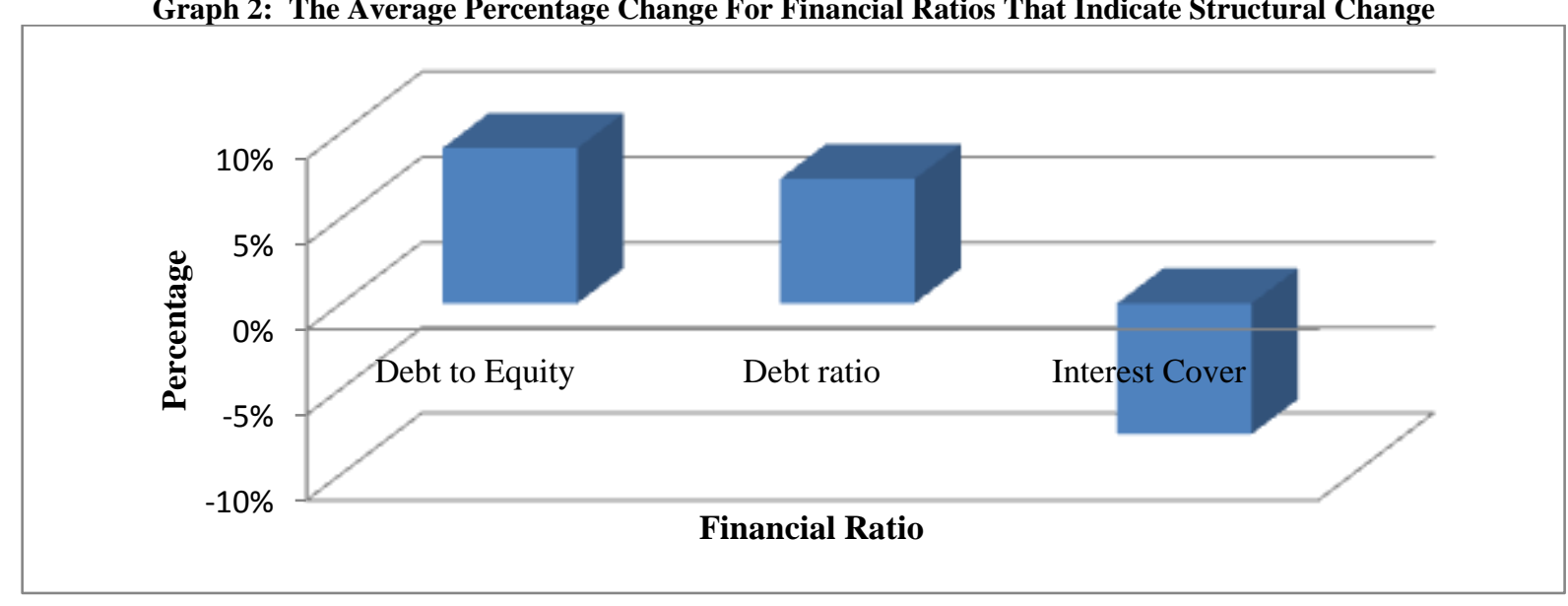

According to Fulbier et al. (2008:128), financial ratios that indicate structural change are a measure of financial and operating risk that investors and companies are exposed to. The structural change ratios that were calculated with the pre- and post-adjusted financial statement results indicate that the level of risk that the investors are exposed to will increase, thereby leading investors to seek a higher return on their investment because of their higher exposure to risk. 


\section{Financial Ratios Measuring The Profitability Of A Company}

As mentioned earlier, the proposed accounting standard on accounting for leases will have an effect on the profitability of a company due to the recognition of the right-of-use asset. This may have a significant impact on the reported profit of a company when impairment losses are recognised according to IAS 36: Impairment of Assets, and/or when amortisation is recognised according to IAS 38: Intangible Assets (IASB, 2010:20-22). The recognition of a liability to make lease payments will result in the recognition of an interest expense.

Graph 3 illustrates the average financial ratios before and after making adjustments to the sampled company's financial statements for the capitalisation of operating leases.

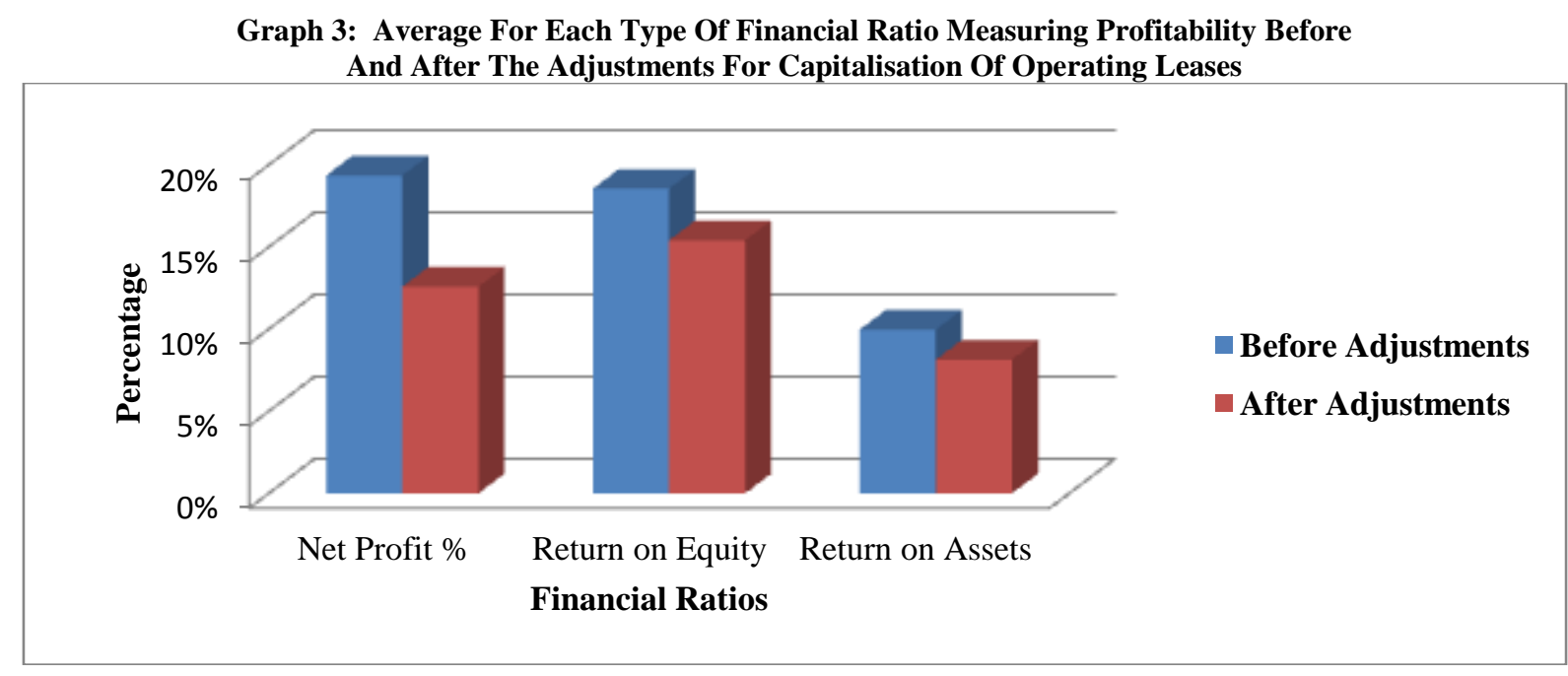

\section{Net Profit Percentage}

The net profit percentage measures the net profit of the company as a percentage of revenue (Etter et al., 2006:172). The interest expense recognised, combined with the amortisation expense, will decrease the net profit together with the resulting deferred taxation effect that arises. The results for the sample, in respect of the pre-and post-adjusted net profit figures, were an average of $19 \%$ and $13 \%$, respectively. This led to an average decrease in net profit percentage of $32 \%$, as indicated in Graph 4.

Graph 4: Average Percentage Change For Each Type Of Financial Ratio Measuring Profitability

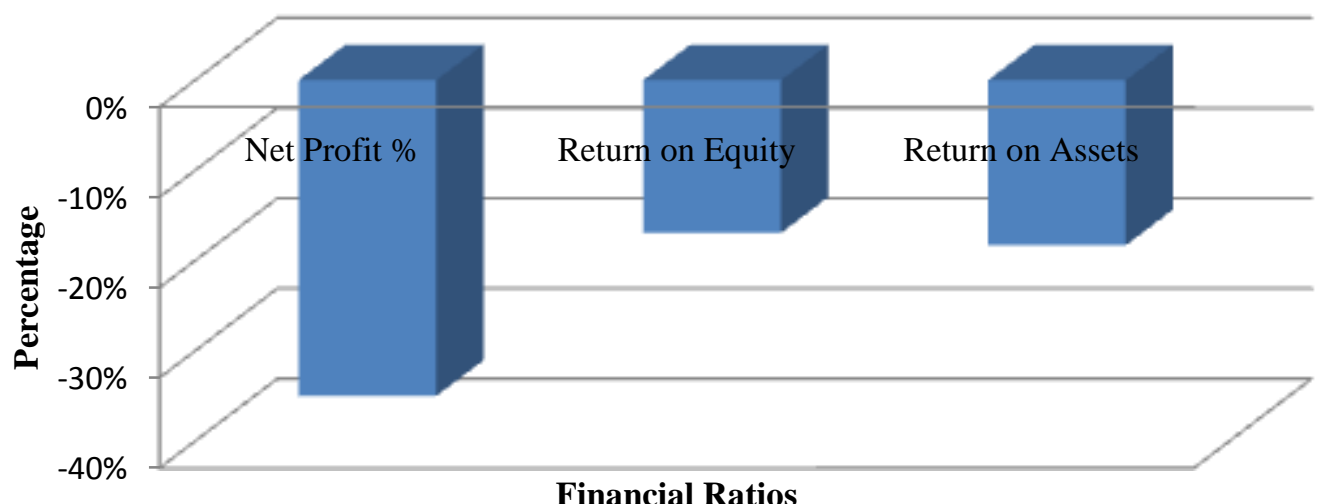

Financial Ratios 


\section{Return On Equity}

Investors seek returns on their investments made in a company. The return-on-equity ratio indicates the return that investors receive on their investments (Halkos \& Salamouris, 2004:2008). If the return-on-equity ratio decreases because of the proposed change to accounting for operating leases by the IASB, it may encourage investors to seek other opportunities for investing their funds so as to ensure that they would receive the return that they require.

After investigating the effect the proposed change would have on the return-on-equity ratio, it was found that the average return-on-equity ratio for the entire sample, before any adjustments to the financial statements, was $19 \%$, as indicated in Graph 4. The post-adjusted financial ratio analysis indicated that the average return-on-equity ratio decreased by $21 \%$ to yield a return on equity of $15 \%$ for the sample. The difference, in return, can be ascribed to a decrease in earnings because of interest as well as amortisation and deferred taxation implications arising from the proposed change in accounting for operating leases.

\section{Return On Total Assets}

The Return-On-Assets Financial Ratio Measures The Return A Company Yields By Employing Its Assets (Correia Et Al., 2011:5-16; Halkos \& Salamouris, 2004:208). The proposed change will not only affect the earnings of the company, but also the total assets because a right-of-use asset will be recognised in the financial statements of the lessee. The sample has an average pre-adjusted return on assets of $10 \%$. Using the post-adjusted financial statements, a return-on-assets ratio of $8 \%$ was calculated, resulting in a decrease of $20 \%$, as illustrated in Graphs 4 and 5 , respectively.

Profitability ratios indicate the company's ability to generate profit. The proposed change in accounting for operating leases does not only affect the earnings of a company, but also the assets used to generate these earnings. When all the ratios measuring profitability are considered, it is clear that a company's profitability may decrease due to the proposed change in accounting for operating leases.

\section{Financial Ratios Affecting The Valuation Of Companies From A Market Perspective}

The valuation of companies from a market perspective includes the use of certain models, such as the priceearnings (PE) model. The proposed change in accounting for operating leases affects the earnings. In effect, this will influence the earnings per share of a company. The price earnings model uses an industry average price-earnings ratio and the market price of the company's shares to value a company. The price-earnings ratio was calculated by dividing the market price of an individual share by the earnings per share. The price-earnings ratio of companies will therefore be affected by the proposed change in accounting for operating leases.

\section{Earnings Per Share}

Earnings per share (EPS) is a ratio that measures the performance of a company and indicates the return that investors yield on their investments (Correia et al., 2011:5-20; Lin et al., 2011). This ratio is of such importance that disclosure with regard to the EPS ratio in the financial statements is mandatory, as stipulated in IAS 33 (IASB, 2009a:1715).

The average EPS for the sampled companies amounted to R16.02 per share, as indicated in Graph 5. 
Graph 5: Average For Each Type Of Financial Ratios Used To Value Companies From A Market Perspective

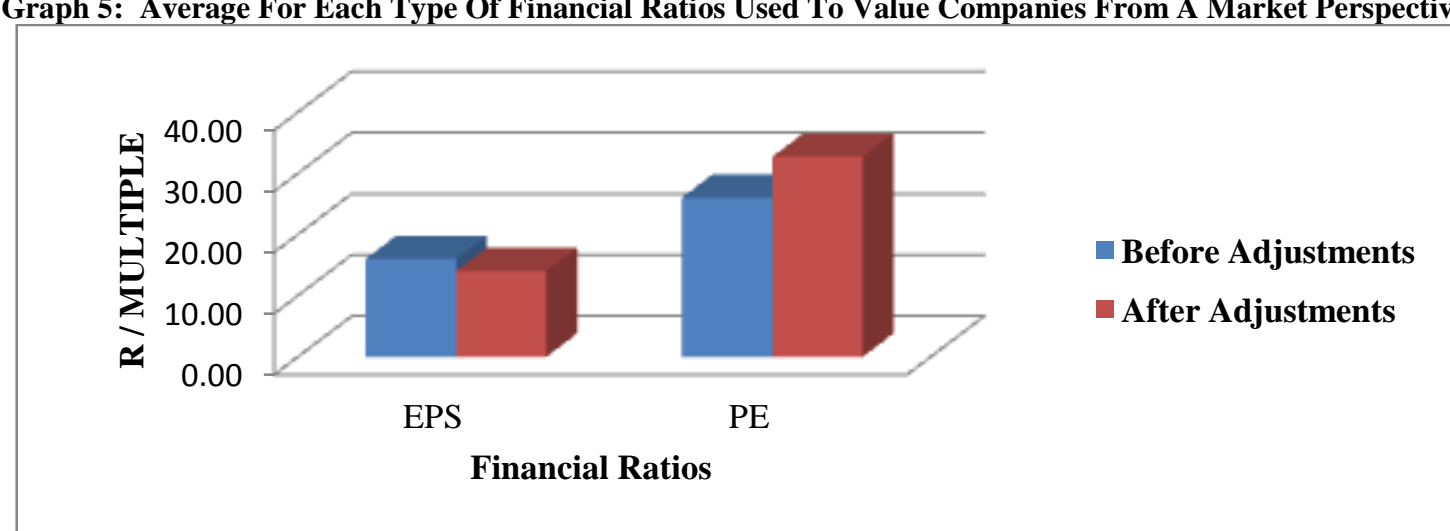

After adjusting the financial statements to account for the proposed change in IAS 17, the average EPS for the sample decreased to R14.05. This results in a decrease of 12\%, as reflected in Graph 6.

Graph 6: Average Percentage Change For Each Type Of Financial Ratio Used To Value Companies From A Market Perspective

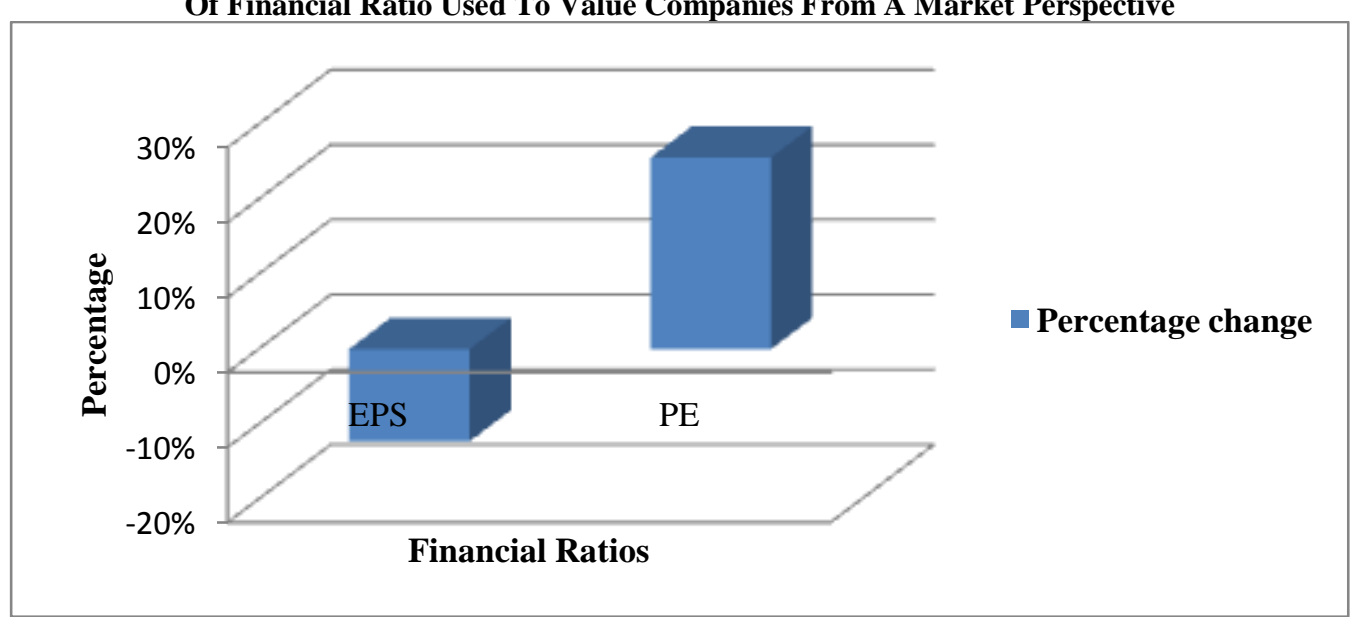

Price-Earnings Ratio

The price-earnings $(\mathrm{PE})$ ratio is used in the price-earnings valuation model to value companies. This ratio indicates the amount that investors are willing to pay per rand of the profits that are disclosed. The PE ratio will be influenced by a movement in earnings and the resulting EPS, as disclosed in the financial statements of a company (Al-Ajmi, 2008:109). In this study, the EPS, on average, decreased because of the proposed change of IAS 17 in connection with operating leases. The result that is expected from the declining EPS is that the PE ratio, on average, should increase if market prices stay constant. This would seem to add value to the company if indeed the price earnings model is used to value the company. It is important to consider the working of the price earnings valuation model. The PE valuation model uses the sustainable earnings multiplied by an average industry PE ratio to estimate a value for the company (Correia et al., 2011), not the PE ratio of the company that is valued. In this study, the average pre- and post-adjusted PE ratios for the sample were calculated as 26 and 33, respectively, resulting in an increase of $26 \%$.

It is therefore clear that the proposed change by the IASB will have a negative impact on the disclosed EPS of companies that take part in operating lease activities. The negative effect is shown in the falling EPS of the companies. The decrease in EPS may encourage investors to seek other companies to invest in to generate a higher return or companies that seem less risky. 


\section{CONCLUSIONS AND RECOMMENDATIONS}

The main objective of this study was to determine the significance of the effect of capitalising long-term operating leases on the financial ratios of the Top 40 JSE-listed companies in South Africa. After considering the conclusions of the literature review and the data analysis performed, it can be concluded that the proposed change by the IASB would significantly affect the financial ratios of the Top 40 JSE-listed companies.

The suggested change of IAS 17 will result in a number of line items and financial ratios to increase or decrease as it reflects the right-of-use asset and the liability to make lease payments that are necessary to ensure that users of financial statements understand the full scope of the leasing activities that companies are engaged in. Recommendations based on the findings include that 1) the effect of this change will have to be communicated to the company's investors as this change will have an effect on their investment in the company and 2) the estimated implications on the share price, as well as the possible effect on the company's Top 40 rating on the JSE together with other stakeholder-related information, should be communicated to the investors. Not only the negative effect, if any, must be communicated, but also what the company's strategy is to ensure that the proposed change of IAS 17 does not significantly affect their share price and the company's Top 40 rating. Some of the strategies to consider include:

- How the company will restructure its financing policy and structures to ensure very little or no effect

- Whether there is a negative effect, what the company's proposal is to ensure that this will be restricted

- What the positive effect of the proposed change to IAS 17 is and how it will enhance the company's ability to generate shareholder wealth

\section{LIMITATIONS AND SHORTCOMINGS}

In relation to the proposed change, as suggested by the IASB, a number of items should be included in the right-of-use asset and liability to make lease payments by discounting them with the incremental borrowing rate of the lessee. These items include 1) the minimum lease payments, 2) contingent rentals, 3) guaranteed residual values at fair value and 4) amounts payable on any renewal options. The disclosure of these items is not mandatory; therefore, only the minimum lease payments were considered in estimating the resulting change in the financial ratios. As the incremental borrowing rate of the lessee will differ from lessee to lessee because of a number of reasons, it was not feasible to obtain the incremental borrowing rate for each company individually. The current prime interest rate in South Africa was used to discount the above-mentioned items.

In considering the minimum lease payments, it was found, due to the grouping effect, that it was necessary to estimate the remaining lease terms and the annual cash flows by making use of the capitalisation model used in the study by Fulbier et al. (2008:127) on listed German companies. This is due to the disclosure requirements in the current IAS 17.

Another limitation is the availability of data relating to the operating lease activities and the applications of the model developed by Fulbier et al. (2008:127). Among the 42 sampled companies, six did not disclose any information about operating lease activities. Of the companies that did disclose information in connection with operating lease contracts, the capitalisation model could not be applied to seven companies, as indicated earlier, making it difficult to come to a conclusion on all the companies in the JSE Top 40. Nonetheless, this study's sample size still constitutes $75 \%$ of the initial population.

\section{AREAS FOR FURTHER RESEARCH}

Areas for further research may include replicating this study to determine the effect on companies not listed or for privately-owned companies. Furthermore, another research design, such as a case study, could be used to determine the effect of operating lease capitalisation on a specific company. This could ensure a more accurate estimation of the effect, as a small sample will ensure that the lease contracts could be investigated on a lease-bylease basis in order to determine the exact remaining lease term, remaining minimum lease payments, and any other items that should be included in the calculation of the present value of the lease payments and investigating the reason for the differences in the findings between this study and studies performed in other countries. 


\section{AUTHOR INFORMATION}

Rikus R de Villiers is currently a senior accountant at KPMG auditing firm in his third and final year of articles. He has passed all the required examinations and will register as a Chartered Accountant (SA) and as a registered auditor at IRBA at the end of the current year. This article is based on the research conducted for his Masters in Commerce (Management Accountancy) degree at the North-West University's Potchefstroom campus in South Africa. Telephone number: +27 79669 1540. E-mail address: rikus.devilliers@ @pmg.co.za

Dr Sanlie L Middelberg is currently a senior lecturer in the School of Accounting Sciences at the North-West University (South Africa), holds a PhD in Management Accountancy and is an Associate Chartered Management Accountant (ACMA). She has worked as Refining Accountant and Senior Internal Auditor at Total South Africa (Pty) Ltd for 5 years. She teaches in the Chartered Management Accountancy and Financial Accountancy programs. Her academic research output includes a number of peer-reviewed articles and conference presentations. Her current research focuses on the area of sustainable agriculture. Telephone number: +27 182994428 E-mail: sanlie.middelberg@nwu.ac.za (Corresponding author)

\section{REFERENCES}

1. Al-Ajmi, J. (2008). The usefulness of Corporate Governance and Financial Ratios to Credit and Financial Analysts: Evidence from Bahrain. European Journal of Economics and Administrative Sciences, 11(1):107125 .

2. Anon. 2009. What determines interest rates? www.online-finance-guru.com Date of access: 10 November 2011.

3. Anon. 2011. Prime interest rate in South Africa. www.liberta.co.za Date of access: 10 November 2011.

4. Beattie, V. (2000). Recognition versus disclosure: An investigation of the impact on equity risk using U.K. operating lease disclosure. Journal of Business Finance \& Accounting, 27(9/10): 1185-1224.

5. Beattie, V., Goodacre, A. \& Thomson, S.J. (2006). International lease-accounting reform and economic consequences: The views of U.K. users and preparers. International Journal of Accounting, 41(1): 75-103.

6. Bryan, S.H., Lilien, S. \& Martin, D.R. (2010). The financial statement effects of Capitalising Operating Leases: Assessing the right of use model. The CPA Journal, 80(8): 36-41.

7. Correia, C., Flynn, D., Uliana, E. \& Wormald, M. (2011). Financial Management $7^{\text {th }}$ edition. Cape Town: Juta.

8. Durocher, S. (2008). Canadian Evidence on the constructive Capitalisation of Operating leases. Accounting Perspectives, 7(3): 227-256.

9. Ely, K.M. (1995). Operating lease accounting and the markets assessment of equity risk. Journal of Accounting Research, 33(2): 397-415.

10. Etter, E.R., Lippincott, B. \& Reck, J. (2006). An analysis of U.S. and Latin American financial accounting ratios. Advances in International Accounting, 19(1): 145-173.

11. Fulbier, U.R., Silvia, J.L. \& Pferdehirt, M.H. (2008). Impact of financial Lease Capitalisation on financial Ratios of Listed German Companies. Schmalenbach Business Review, 60: 122-144.

12. Generally Accepted Accounting Principles in the United States. (2011). Leases: Codification 840 [Online]. Available at: http://cpaclass.com/gaap/gaap-us-01a.htm [accessed 2011-8-31].

13. Grossman, A.M. \& Grossman, S.D. (2010). Capitalising lease Payments: Potential affects of the FASB/IASB plan. The CPA Journal, 80 (5):6-11.

14. Halkos, G.E. \& Salamouris, D.S. (2004). Efficiency measurement of the Greek commercial banks with the use of financial ratios: a data envelopment approach. Management Accounting Research, 15(1): 201-224.

15. Horrigon, J.O. (1965). Some empirical basis of financial ratio analysis. The Accounting Review, 40(3):558568.

16. IASB see International Accounting Standards Board.

17. Imhoff, E.A., Lipe, R. \& Wright, D.W. (1993). The effects of recognizing versus disclosure on stakeholder risk and executive compensation. Journal of Accounting, Auditing \& Finance, 8 (4): 335-368.

18. International Accounting Standards Board. (2009a). Volume 1B. IAS 17 Leases. London: International Accounting Standards Committee Foundation. 1978p. 
19. International Accounting Standards Board. (2009b). Volume 1 A. Framework. London: International Accounting Standards Committee Foundation. 1002p.

20. International Accounting Standards Board. (2010). Leases: Classification and measurement (ED/2010/9) [Online]. Available at: www.iasb.org [accessed 2011-8-2].

21. Koen, M. \& Oberholzer, J. (1999). Ontleding en vertolking van Finansiële State. LANSDOWNE: Juta \& Kie. 136 p.

22. Lin, F., Liang, D. \& Chen, E. (2011). Financial ratio selection for business crisis prediction. Expert Systems with Applications - Journal, 38(1): 15094-15102.

23. Mohr, P. (2011). Economic indicators. Pretoria: Unisa Press. 239p.

24. Nadarajah, S. \& Kotz, S. (2007). Generalized financial ratios. Mathematical Methods in the Applied Sciences, 30(1): 995-1001.

25. US GAAP see Generally Accepted Accounting Principles in the United States.

26. Vigario. F. (2008). Managerial Finance. Johannesburg: LexisNexis. 479p.

27. Wilkins, T. \& Zimmer, I. (1983a). The effect of leasing and different methods of accounting for leases on credit evaluations. The Accounting Review, 58 (4): 749-764.

28. Wilkins, T. \& Zimmer, I. (1983b). The effects of alternative methods of accounting for leases - an experimental study. Abacus, 19 (1): 64-75. 
NOTES 